populations afford the most serious problems in their steadily increasing demands.

The White Paper was discussed on a motion moved by the Minister of Health, Mr. Willink, in the House of Commons on May 3. While the statement received a general welcome, there was criticism from all sides that the suggested procedure was slow and the scheme lacked boldness. Mr. Willink said that the main instrument for collecting information on the yield and quality of water resources is the Inland Water Survey, and the Government proposes to press on with it at the earliest possible date. The Central Advisory Water Committee, with new powers, would advise the Minister of Health on general policy in the light of the information provided by the Survey. As an alternative to this Central Committee, a national water board under a strong, well-qualified chairman, was suggested as a means of co-ordinating the water policy of Great Britain. Against this suggestion it was urged by the Minister of Agriculture, Mr. R. S. Hudson, that water policy touched on too many aspects of national administration, such as housing, health, drainage and agriculture, to make a national water board feasible and practicable.

\section{Regional Organization in Australasia}

THE Agreement between the Commonwealth of Australia and the New Zealand Governments signed at Canberra on January 21, 1944, has now been published (Cmd. 6513). In addition to undertaking general collaboration with regard to the location of machinery set up under international organizations such as the United Nations Relief and Rehabilitation Administration, the two countries agree to promote the establishment of a regional organization with advisory powers, which could be called the South Seas Regional Commission, on which the Governments of the United Kingdom, the United States and the French Committee of National Liberation might be represented. Such a Commission would have as its function to secure a common policy on social, economic and political development directed towards the advancement and well-being of the inhabitants themselves and, particularly, the Commission would recommend arrangements for the increasing participation of local inhabitants in administration, with a view to the ultimate attainment of self-government in the form most suited to the circumstances of the peoples concerned; arrangements for material development, including production, finance, communications and marketing; for the co-ordination of health and medical services and education; for the maintenance and improvement of labour conditions and social services as well as collaboration in economic, social, medical and anthropological research.

The publication of periodical reviews of progress in this field is also visualized, and in addition to the establishment of a regional zone of defence and of permanent machinery for collaboration and co-operation between Australia and New Zealand, the Agreement provides for joint action in support of the principles that full control of the international air trunk routes and the ownership of all aircraft and ancillary equipment should be vested in an international air transport authority operating those routes, and that the routes themselves should be specified in an international agreement. Failing such agreement the two Governments support a system of air trunk routes controlled and operated by Governments of the British Commonwealth of Nations under Government ownership.

\section{Colonial Geological Surveys}

THE function and future of the Colonial Geological Surveys formed the subject of a recent article in Nature $(153,273 ; 1944)$, in which a discussion on the matter, held under the joint auspices of the Geological Society of London and the Institution of Miaing Engineers in November last, was summarized at some length. The subject has again been dealt with in the Bulletin of the Imperial Institute (41, No. 4, 255; 1943), by the 'intelligence staff' of the Institute, under the heading "A Review of Geological Survey Work in the Colonies". In this article the authors refer to all the Colonies except those small islands and groups where, it is stated, the question of establishing official Surveys scarcely arises. Particulars are given separately for each Colony as to area, the years, if any, during which geological survey work has been carried out, the amounts of money expended on such work, the staffs employed and the maps that have been published. Reference is also made to the question of water-supply and to mining activities. With few exceptions, it appears that in none of the colonies was a Geological Survey established earlier than 1918. In Ceylon, a mineral survey was commenced in 1903; and in British Malaya a Geological Survey has existed for forty years, though until 1912 it employed only one geologist. In certain other Colonies short-term mineral surveys were carried out in the early years of this century by the Imperial Institute, under the auspices of the Colonial Office.

The information supplied is based on published records, and it certainly provides factual support for the views expressed at the joint meeting of the Geological Society and the Institution of Mining Engineers at their joint meeting last year. It makes it clear, in fact, that there is ample room for enlargement, and improvement in the continuity and scope, of the work of the Colonial Geological Surveys. Actually the matter is in hand, for the Secretary of State for the Colonies has appointed a panel of experts to advise him on the subject. The intention of the authors of the Imperial Institute article is to point out the desirability that a fair share of the Colonial Office grants for the extension of scientific investigation into Colonial problems should be allocated to the expansion of geological survey work. In the view of the Institute, a Geological Survey should be regarded as a public service available to the mining, agricultural and other industries; as well as for government-sponsored public works and water supply services; and also as an educational institute. The association of the Imperial Institute with the Colonial Geological Surveys is one of long standing, and the recommendations made in this article, backed by an authoritative statement of facts, should command the attention of those interested in the welfare and development of the Colonies.

\section{Archæological Find in Kenya}

DR. L. S. B. LeakeY, honorary curator of the Coryndon Museum, who is employed in war-time duties with the C.I.D., Nairobi, has spent eighteen days leave on Site 10 at Mount Olorgasailie in Kenya, accompanied by Mrs. Leakey, Mr. A. J. Arkell, the Commissioner for Archæology in the Sudan, Miss E. Cory, Mr. F. de V. Kirk and Mr. G. Alkin. The excavations carried out showed that the surface indications noted early in 1942 had not been misleading and that the site is of outstanding importance. 